\title{
Pusher Device
}

National Cancer Institute

\section{Source}

National Cancer Institute. Pusher Device. NCI Thesaurus. Code C54023.

A device designed to advance something by pushing it. 